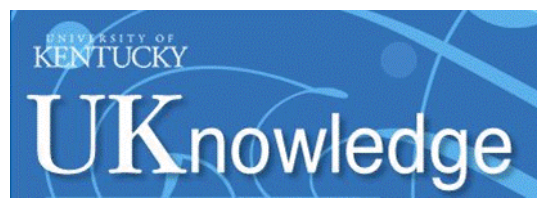

University of Kentucky

UKnowledge

\title{
Energizing miRNA Research: A Review of the Role of miRNAs in Lipid Metabolism, with a Prediction that miR-103/107 Regulates Human Metabolic Pathways
}

\author{
Bernard R. Wilfred \\ University of Kentucky, bernard.wilfred@uky.edu \\ Wang-Xia Wang \\ University of Kentucky, wwangc@uky.edu \\ Peter T. Nelson \\ University of Kentucky, pnels2@email.uky.edu
}

Follow this and additional works at: https://uknowledge.uky.edu/sbcoa_facpub

Part of the Geriatrics Commons, Neurosciences Commons, and the Pathology Commons

Right click to open a feedback form in a new tab to let us know how this document benefits you.

\section{Repository Citation}

Wilfred, Bernard R.; Wang, Wang-Xia; and Nelson, Peter T., "Energizing miRNA Research: A Review of the Role of miRNAs in Lipid Metabolism, with a Prediction that miR-103/107 Regulates Human Metabolic Pathways" (2007). Sanders-Brown Center on Aging Faculty Publications. 104.

https://uknowledge.uky.edu/sbcoa_facpub/104

This Review is brought to you for free and open access by the Aging at UKnowledge. It has been accepted for inclusion in Sanders-Brown Center on Aging Faculty Publications by an authorized administrator of UKnowledge. For more information, please contact UKnowledge@lsv.uky.edu. 


\section{Energizing miRNA Research: A Review of the Role of miRNAs in Lipid Metabolism, with a Prediction that miR-103/107 Regulates Human Metabolic Pathways}

Digital Object Identifier (DOI)

https://doi.org/10.1016/j.ymgme.2007.03.011

Notes/Citation Information

Published in Molecular Genetics and Metabolism, v. 91, issue 3, p. 209-217.

Copyright @ 2007 Elsevier Inc.

(c) 2007. This manuscript version is made available under the CC-BY-NC-ND 4.0 license http://creativecommons.org/licenses/by-nc-nd/4.0/. 


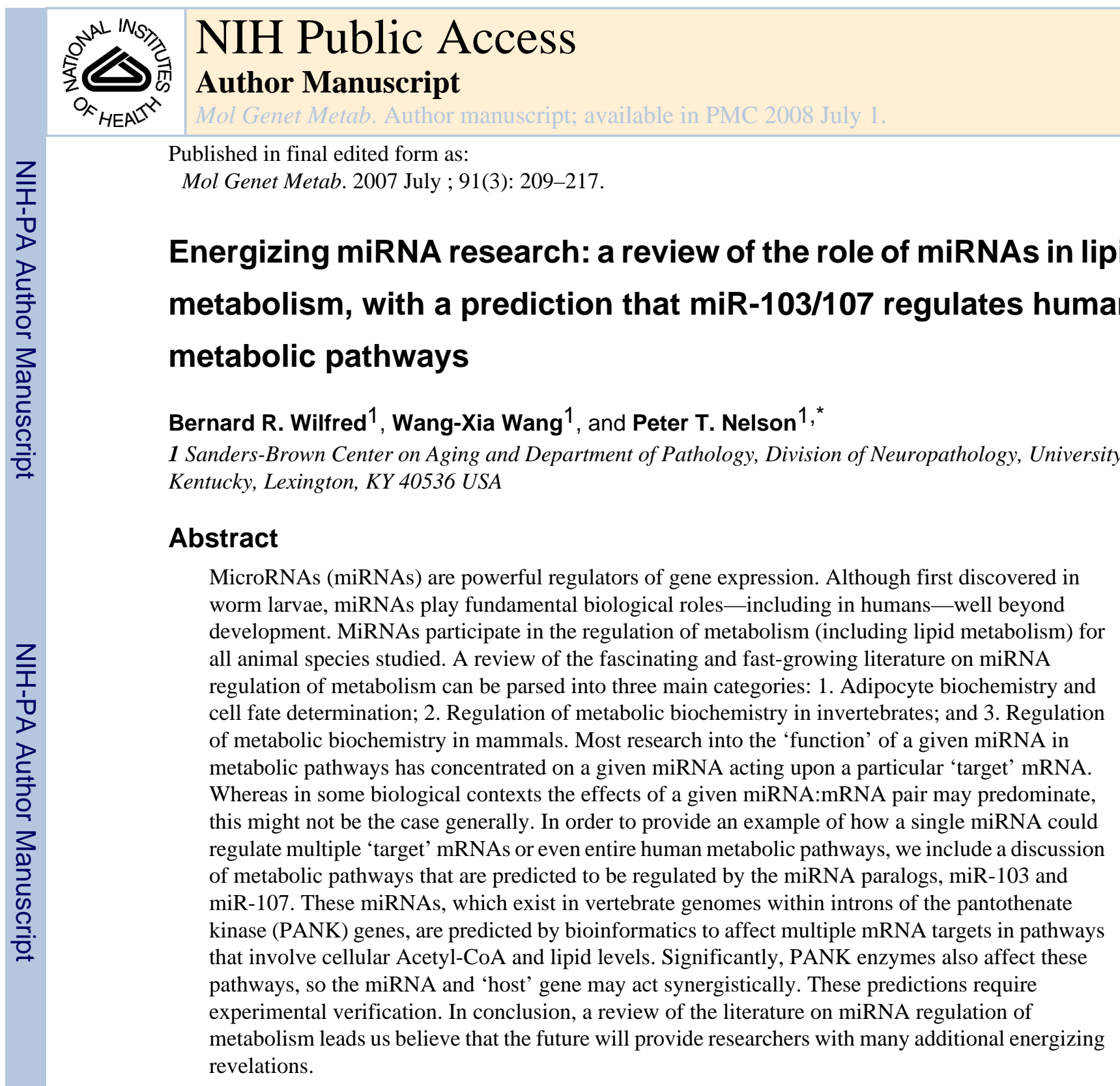

\section{Keywords}

lipids; metabolism; brain; Acetyl-CoA; miRNAs; microRNA; miR-107; miR-103; PANK; pantothenate

\section{Introduction}

MicroRNAs (miRNAs) are small regulatory RNAs that play fundamental biological roles in all known plant and animal species. Translational regulation by miRNAs has emerged as a complex biological paradigm, involving interdependent genes and pathways. Many of the

*Corresponding Author: Peter T. Nelson MD PhD, 311 Sanders-Brown Center on Aging, 800 S Limestone, University of Kentucky, Lexington, KY 40536-0230, Ph \# (859) 257-1412 x 254, Fx \# (859) 257-6054, peter.nelson@uky.edu

Publisher's Disclaimer: This is a PDF file of an unedited manuscript that has been accepted for publication. As a service to our customers we are providing this early version of the manuscript. The manuscript will undergo copyediting, typesetting, and review of the resulting proof before it is published in its final citable form. Please note that during the production process errors may be discovered which could affect the content, and all legal disclaimers that apply to the journal pertain. 
genes regulated by miRNAs are also involved in metabolism, including in pathways involved in lipid biochemistry. The regulation of metabolism by miRNAs is only partly understood. However, a review of the literature provides early indications that miRNA research will be energizing researchers in the field for years to come.

A grasp of basic miRNA biochemistry is required to consider how miRNAs could regulate metabolic pathways. Fundamental miRNA biology has been well reviewed previously[1-4]. In the human genome, miRNA genes can exist singly or can be co-transcribed in a 'polycistronic' arrangement[5,6]. Many miRNAs are paralogous (i.e., similar to one another and possibly derived from gene duplication). The transcription and downstream processing of miRNAs is complex and beyond the scope of this review[7-14]. Briefly, miRNAs are transcribed from intergenic regions, from introns, or more infrequently from within exons of known protein-coding genes[15]. Intronic miRNAs may be co-transcribed with the 'parent' mRNAs (usually by RNA polymerase II), or may be transcribed independently[15-18]. Large precursor RNAs called "pri-miRNAs" are sequentially cleaved in the nucleus, exported to the cytoplasm, and then processed further to produce 'mature' ( 22 nucleotides in length) singlestranded miRNAs that are bound to Argonaute proteins[19,20]. MiRNAs are thought to function by recognizing 'target' mRNAs through partial base-pair complementarity, and this recognition leads to a decrease in the rate at which a polypeptide is correctly formed from that mRNA template. As shown in Fig. 1, the specificity of the interaction is conferred by the miRNAs, but the translational inhibition is coordinated by miRNA-associated Argonaute proteins. The mechanism(s) by which Argonaute proteins function have been at least partly described [21-24]. It should be noted that targeted mRNAs may be preferentially degraded, so that translational regulation is not the only mechanism by which miRNAs work[25,26].

Complementing cellular and molecular biological studies, bioinformatics have also been very important in driving the field of miRNA research. Among other things, bioinformatics techniques are used to predict which miRNAs can regulate which target mRNAs[27-34]. Theses studies involve the cross-correlation between miRNA sequences and potential hybridizing sequences in known and annotated genomes. Individual miRNAs can each recognize many different mRNAs, up to a thousand or more [29,35]. Thus it is considered that $40-90 \%$ of human mRNAs are regulated by known miRNAs (and many more miRNAs are probably unknown)[35,36]. The prediction algorithms for miRNA interactions with mRNAs vary, however, these criteria are considered important: 1. metazoan miRNA recognition sites are thought to reside within the 3'UTR (untranslated region) of target mRNAs ([37,38]; however see [39]); 2. the $5^{\prime}$ half of the miRNA appears most important in binding to mRNAs [31,40]; and, 3. mRNA 3'UTR sequences demonstrate relative evolutionary degeneration (i.e., increased numbers of mutations), so potential 3'UTR target mRNA sequences that are evolutionarily conserved and also recognized by miRNAs are thought to most likely represent genuine miRNA recognition motifs whose function confers a fitness advantage (see [30,32, $34])$.

\section{Research on the role of miRNAs in metabolism}

Boinformatics and bench research have combined to establish that miRNAs participate in fundamental functions in animal and plant biology. Accordingly, miRNAs participate in metabolism--making energy available to an organism. Thus far research in this field is in its infancy, and much remains to be learned (for excellent prior reviews, see [41-44]). Some research findings will be summarized below with an emphasis on the metabolism of lipids. These studies, which are summarized in Table 1, fall under three categories: 1. Adipocyte biochemistry and cell fate determination; 2 . Regulation of metabolic biochemistry in invertebrates; and 3. Regulation of metabolic biochemistry in mammals. 


\section{MiRNA regulation in adipocytes in culture}

MiRNAs were discovered in the context of the heterochronic developmental pathway in $C$. elegans $[45,46]$. Hence, it is well known that miRNAs can play a role in development and cell fate determination. Adipocytes are cells which provide retrievable fat and energy depots in animal species. Several labs have now found evidence that miRNAs are involved in the developmental maturation of adipocytes from precursor cells called pre-adipocytes. These experiments have mostly involved cultured pre-adipocytes, which can be stimulated to differentiate into a phenotype resembling mature fat-storing adipocytes. Kajimito et al [47] found in 3T3-LI pre-adipocytes in culture, 80 different miRNAs are expressed and 21 individual miRNAs are differentially expressed in the course of pre-adipocyte differentiation (most of the changes taking place in the late stages of differentiation). However, inhibiting the function of individual miRNAs (including miR-143) did not alter the course of the preadipocyte differentiation, nor did these perturbations alter the mRNA levels of marker genes PPAR-gamma, A-FABP, or adiponectin. In these cells, both miR-103 and miR-143 tended toward higher expression in more differentiated cells. Esau et al [48] demonstrated in cultured human pre-adipocytes that inhibiting miR-143 also inhibited adipocyte differentiation in those cells, and the authors hypothesized that this effect may occur through the targeting by miR-143 of the mRNA for the protein ERK5. Hence in cells whose physiological function is involved in lipid metabolism, miRNAs are abundant, and may play a role in determining the terminal cell phenotype.

In addition to playing a role in adipocyte cell fate determination, bioinformatics have been applied to predict a major role for miRNAs in the steady-state function of pre-adipocytes and adipocytes. Hackl et al [36] performed high-throughput analyses of the 3' UTR from ESTs expressed in 3T3-LI pre-adipocyte cells. Data derived from the study of hundreds of ESTs showed that $>70 \%$ of differentially expressed genes are predicted to be regulated by miRNAs that were known at that time. Many of the mRNAs predicted to be regulated by miRNAs encoded transcription factors, so the effects of miRNA regulation may be amplified. These data are highly suggestive that miRNAs play important, dynamic roles, in regulating the function of fat cells.

\section{Regulation of metabolic biochemistry in invertebrates}

Although cells in culture offer advantages for experimental manipulation, invertebrate models can be used to study whole-animal genetics. Metabolic regulation occurs at many different interdependent levels and miRNA regulation may be involved at all levels of regulation. Intriguing results have been obtained in Drosophila with regard to individual miRNAs with organism-level regulation of metabolic pathways. These pathways intersect with other aspects of those animals' biochemical milieu. Teleman et al [49] demonstrated that flies that lack a particular miRNA (miR-278) have metabolic defects. MiR-278 (a miRNA expressed most abundantly in Drosophila adipose tissue) mutants have increased insulin production and lower levels of adipose, but also have elevated circulating glucose levels due to increased glycogen mobilization, and decreased insulin sensitivity. These changes are hypothesized to involve a pathway that incorporates the polypeptide product of the gene expanded. Xu et al [50] showed the importance of another Drosophila miRNA--miR-14--to energy metabolism at the wholeanimal level. MiR-14 evidently plays a role in fat metabolism, as well as in cell death, and also in the animals' response to environmental stress. Animals with miR-14 deletions have increased circulating fats, and increased peripheral lipid droplets. The authors speculate on the role for miR-14 in 'lipoapoptosis'. There are no known exact human orthologs to Drosophila miR-14 and miR-278. However, some human miRNAs show sequence homology: human miR-511 and miR-620 resemble Drosophila miR-14, and human miR-658 and miR-583 resemble Drosophila miR-278 (for example, the sequence for hsa-miR-658 shares 15 of 22nts in sense orientation with dme-miR-278). Whether or not these miRNAs play a role in human 
metabolism remains to be seen. Dovetailing on the work in fruit flies is research involving metabolism and miRNAs in worms[51]. C. elegans was the species in which miRNAs were first discovered and these animals continue to be a source of insights into miRNA biology. Boehm and Slack [52] showed that in worms, as in fruit flies, lifespan and metabolic pathways interact through pathways that include miRNAs and insulin processing.

\section{Regulation of metabolic biochemistry in mammals}

Recent work in mammalian metabolism has complemented the earlier, and on-going, invertebrate studies. This research introduces new paradigms in both mammalian metabolism and miRNA biochemistry. Poy et al [53] studied miRNAs in mouse pancreas, and reported that miRNAs can be involved in the dynamic biochemistry of the cell. This important finding shows that miRNAs don't merely regulate discreet developmental stages (i.e., cell fate determination). In these studies they found that mouse insulin secretion is regulated by the pancreatic miRNA mmu-miR-375, an evolutionarily-conserved islet-specific miRNA. Myotrophin is evidently the target of miR-375, and this miRNA:target interaction regulates the secretion of insulin. The regulation of exocytosis machinery is probably a widespread phenomenon because many miRNAs are predicted to target exocytosis-related proteins[41]. Plaisance et al [54] showed that miR-9 causes a reduction in exocytosis in pancreas (insulinsecreting beta cells) that is elicited by stimuli including glutamate. MiR-9 is hypothesized to act in this context ultimately by affecting the concentration of granulophilin/Slp4. This effect, mimicked by various pharmacological and biochemical means, demonstrates that a miRNA can be active in maintaining metabolism-related function in endocrine cells. It should be noted that miR-9 is also predicted to regulate almost 1000 other target mRNAs[29], and miR-9 is very concentrated in the human brain[16,55], where it may be related to malignant transformation of glioma cells [56].

One of the few published examples of miRNAs regulating a metabolic pathway per se involves miR-29b, which Mersey et al [57] demonstrate may be involved in the metabolism of amino acids in HEK 293 cells. This activity evidently occurs through regulation of the mRNA for the dihydrolipoamide branched chain acyltransferase subcomponent of the branched chain alphaketoacid dehydrogenase (BCKD) complex. This finding is very significant because it places miRNAs for the first time in a mammalian species as a co-regulator of a complex metabolic pathway. In sum, mammal-oriented research on miRNA regulation of metabolism has given us new insights into the roles that miRNAs can play. However, every new datum thus far has only indicated that we probably have much more yet to learn.

The focal point of many lines of research is therapy for human diseases, and the miRNA pathways are excellent candidates for pharmacological manipulation[58-61]. Fascinating recent work [62,63]demonstrates that the regulation of metabolic pathways in humans is of direct, practical interest as a candidate for therapeutic measures. Esau et al [63] focused on the miRNA pathway itself as a potential target for pharmacological intervention in an animal model. This study involved the injection of a miR-122 antagonist (an antisense oligonucleotide with 2'-O-methoxyethyl phosphororothiate) into mice that resulted in decreased plasma cholesterol levels and hepatic fatty acid and cholesterol synthesis. Fatty acid metabolism was altered with decreased amounts of fatty acid metabolism-related mRNA levels for genes such as ACACA, ACACB, ACLY, FASN, LIPC, SCD1, and others. The authors proposed that this reagent would be a good therapeutic candidate for metabolic disease. 


\section{Bioinformatics predict a role for miR-103/miR-107 paralogs in lipid and energy metabolism}

With some notable exceptions described above, most research about the 'function' of a given miRNA in metabolism has concentrated on the impact of a particular miRNA:mRNA interaction. Whereas the effects of a given miRNA:mRNA pair may predominate in some biological contexts, this may not generally be true. After all, many miRNAs are predicted by bioinformatics to help regulate well over 1,000 different target mRNAs[29,35]. In order to provide an example of how a given miRNA could alter entire human metabolic pathways, this review incorporates a discussion of a metabolic pathway in which multiple different mRNAs may be regulated by a few, highly-similar miRNA genes.

A review of the literature reveals multiple references to three human miRNA paralogs: miR-103(1), miR-103(2), and miR-107. These references, along with some additional data mining from public access databases, leads us to conclude that these paralogous miRNAs may play a role in human metabolism. MiR-103 genes encode two identical mature miRNAs, and a third paralogous miRNA termed miR-107 differs at a single nucleotide (both were first cloned and sequenced by Mourelatos et al [64] from Hela cells). All three paralogs reside on different human chromosomes (see Fig 2). miR-103 and miR-107 genes are absolutely conserved in all known vertebrates but are not described in any invertebrate species. Some hybridization-based profiling experiments may be nonspecific, because probes for miR-103 and miR-107 may cross-hybridize. (Because of the near-complete sequence homology, and because there has not been shown to be a very significant difference in the expression of these genes, we will refer collectively to ' $m i R-103 / 7$ '). Nonetheless, miR-103/7 have been shown to be expressed in many human organs with highest concentration in brain tissue [16,55]. MiR-103/7 are differentially expressed in a number of contexts, including during development[48,65], oncogenesis[66], hypoxia[67], and both cold and heat stress[68,69]. The significance of stimuli-induced changes in miR-103/107 expression has not been described. It is also of unknown significance that, within the critical 5' portion of miR-103/7, there is close homology to the miRNAs miR-15 and miR-16. Both miR-15 and miR-16 are highly-expressed during vertebrate development, and linked directly to human cancer [70].

The DNA templates for miR-103(1), miR-103(2), and miR-107 exist for all known vertebrates within introns in the genes that encode the pantothenate kinase (PANK) enzymes. In humans, there are at least three highly-homologous PANK genes. MiR-103(1), miR-103(2), and miR-107 reside within PANK 3, PANK 2, and PANK1 genes, respectively. The basic arrangement of these miRNAs in PANK genes remains constant through vertebrate evolution, from species as varied as Tetraodon nigroviridis, Danio rerio, Fugu rubripes, Xenopus tropicalis, Gallus gallus, Mus musculus, and Homo sapiens. The only difference is that for a few species there is no apparent miR-103(2). The common evolutionary relative of these species lived $\sim 500$ million years ago during the advent of invertebrates.

In order to understand the significance of the association of PANKs and miR-103/7 in the vertebrate genome, it is important to consider the function of the polypeptide encoded by the PANK gene. PANK enzymes serve a universal catalytic function, namely, the phosphorylation of pantothenate (Vitamin B5)[71]. This is the rate-limiting step in generating Co-enzyme A (CoA) and PANKs are central enzymes in the regulation of cellular CoA levels[71-75]. CoA is a necessary cofactor in $\sim 4 \%$ of known enzymes, including over a 100 reactions involved in metabolism[73,76]. These enzymatic reactions include important steps in the metabolism and synthesis of fatty acids, amino acids, cholesterol, pyruvate/lactate, glucose, and Krebs cycle intermediates, to name a few. Interestingly, PANK2 is a gene which harbors loss-of-function deletions in a pediatric neurodegenerative disease, termed Pantothenate kinase associated neurodegeneration (also kown as 'Neurodegeneration with brain iron accumulation', formerly 
Hallervorden-Spatz syndrome)[77-79]. Neuropathologically, Pantothenate kinase associated neurodegeneration is characterized by loss of neurons, iron pigment deposits, and axonal swellings that are most conspicuous in the basal ganglia. It is not yet known how the expression of miR-103 (2), which resides in PANK2 gene, is altered in that condition.

The location of miR-103/7 genes within introns of the PANK genes may be physiologically relevant. Expression levels of intronic miRNAs and their host genes often are highly correlated, presumably because they are co-transcribed $[16,18]$. In the case of miR-103, the miRNA expression level were indirectly correlated with expression coefficients of 0.638 (PANK2) and 0.270 (PANK3)[16]. MiR-107/PANK1 levels have not been correlated. Data from microarray experiments of mammalian tissues indicate that miR-107 and miR-103 are expressed in most or all tissues but are evidently expressed at highest levels in the brain [16,55]. There are no prior studies that demonstrate PANK levels in brain (but see [80]), however, we find robust expression of all three PANK transcripts in human brain (our unpublished results).

Bioinformatics predict that miR-103/7 regulate metabolism with an emphasis on acetyl-CoA and lipid metabolism. This is doubly interesting because PANKs regulate similar pathways. Four different public-access databases were 'mined' in this study: MiRANDA (2005 build), MiRANDA (2006 build), PicTAR, TARGETSCAN [27-29]. The latter 3 databases are accessible through the Rfam miRNA registry, whereas the miRANDA 2005 build is accessed through the Memorial Sloan Kettering website. These databases are each public access with Web URLs as described in the Fig 3 legend. Each of these databases has different criteria for predicting miRNA recognition elements in the 3'UTR of predicted mRNAs. MiRANDA 2005 and 2006 builds have rather different target predictions, because each uses different search criteria. As shown in Fig. 3, many more mRNAs are predicted to be recognized by the miRNAs than are shown here (for example, miRANDA predicts that over 1000 transcripts are recognized by miR-103/107). Only genes well-known to be involved in metabolic pathways were used in these analyses. However, it should be noted that these genes were not 'cherry-picked', and all evaluated genes relevant to this discussion are shown. Figure 3 shows the results of five additional miRNAs which, like miR-103/7, are all highly-expressed in brain. This figure shows the total number of mRNA targets predicted by the various databases by the relevant miRNAs, for comparison with the results of miR-103/7. Note that while miR-103/7 is predicted to target many enzymes that are important in regulating metabolism, this is not true of most other miRNAs, even miRNAs that are predicted to recognize more target mRNAs overall. For example, the PDK4 mRNA transcript has a $\sim 2.1 \mathrm{~kb}$ long $3^{\prime} \mathrm{UTR}$ and all four databases predict that miR-103/7 recognition sequence(s) are present there, however, other miRNAs shown are not predicted to recognize sequences in this $3^{\prime} \mathrm{UTR}$.

MiR-103/7 are predicted to act on genes in metabolic pathways in a manner that suggests a coordinated function with the PANK genes (see Fig. 4). As mentioned above, the PANK genes are known to be central players in regulating intracellular CoA[71-75]. Here we see that miR-103/7 also acts to increase intracellular Acetyl CoA stores, and perhaps channel Acetyl CoA into the TCA cycle. A PPAR-alpha targeted promoter has been discovered 5'upstream to the PANK1 gene[81]. PPAR-alpha receptors are transcription factors that are stimulated by increased (among other things) intracellular lipids/fatty acids; the function of PPAR-alpha is thought to involve decreasing intracellular FA stores (FAs)[82-86]. These results suggest that miR-103/7 acts symbiotically with the PANK proteins and the PPAR-alpha pathway, by decreasing FA syntheses and uptake (by inhibiting FASN, ACOX1, and others), and increasing the activity of the pyruvate dehydrogenase complex (by inhibiting PDK4, PISD, and PDPR).

It remains to be proven experimentally that miR-103/7 regulate multiple mRNA targets in a pathway that involves cellular Acetyl-CoA and lipid levels. However, there are five summary points that are strongly suggestive: 1 . MiR-103/7 are present in PANK genes, which serve to 
regulate metabolism (and this relationship holds constant through vertebrate evolution); 2. Prior studies suggest that intronic miRNAs are often expressed coordinately with their 'parent' protein-coding genes[15,16,18]; 3 . MiR-103/7 levels are changed in states of altered cellular metabolism, including stress $[48,65,66,68,69] ; 4$. Most miRNAs are not predicted to target mRNAs that encode proteins that are rate-determining enzymes in metabolic pathways (see Fig. 3); 5. Bioinformatics predict that miR-103/7 recognizes motifs in the $3^{\prime}$ UTR of particular target mRNAs in metabolic pathways in a pattern that appears to complement the activity of PANK.

\section{Conclusion}

Studies from diverse biological systems have provided evidence for miRNAs participating in metabolic pathways. Experiments in invertebrates have determined that particular miRNAs have important multimodal effects that include changing the metabolism of lipids. Research in mammals has shown that miRNAs affect metabolism at many levels, including the regulation of insulin secretion in pancreas. MiRNAs also apparently play a role in determining the cell fate and physiology of human adipocytes. Also, miRNA-related pathways have been shown to be an attractive candidate for pharmacological treatment of human metabolic syndromes. With regard to 'classical' metabolic pathways, miR-29b participates in regulating amino acid metabolism, and, pending experimental verification, miR-103/7 may complement PANK genes to regulate cellular Acetyl-Coa and lipid levels.

In summary, research in miRNAs in metabolism spans many species and experimental systems. Even in the context of a literature review, it is utterly impossible to relate all the work in a single conceptual framework. Yet there is a common message underlying it all: this powerful regulatory paradigm will probably provide to researchers many, many additional energizing discoveries.

\section{Acknowledgements}

Funding was provided by NIH K08 NS050110.

\section{References Cited}

1. Nelson P, Kiriakidou M, Sharma A, Maniataki E, Mourelatos Z. The microRNA world: small is mighty. Trends Biochem Sci 2003;28(10):534-40. [PubMed: 14559182]

2. Ambros V. The functions of animal microRNAs. Nature 2004;431(7006):350-5. [PubMed: 15372042]

3. Engels BM, Hutvagner G. Principles and effects of microRNA-mediated post-transcriptional gene regulation. Oncogene 2006;25(46):6163-9. [PubMed: 17028595]

4. Kosik KS, Krichevsky AM. The Elegance of the MicroRNAs: A Neuronal Perspective. Neuron 2005;47 (6):779-82. [PubMed: 16157272]

5. Chung KH, Hart CC, Al-Bassam S, Avery A, Taylor J, Patel PD, Vojtek AB, Turner DL. Polycistronic RNA polymerase II expression vectors for RNA interference based on BIC/miR-155. Nucleic Acids Res 2006;34(7):e53. [PubMed: 16614444]

6. Weber MJ. New human and mouse microRNA genes found by homology search. Febs J 2005;272(1): 59-73. [PubMed: 15634332]

7. Costa FF. Non-coding RNAs: Lost in translation? Gene 2007;386(1-2):1-10. [PubMed: 17113247]

8. Mendell JT. MicroRNAs: critical regulators of development, cellular physiology and malignancy. Cell Cycle 2005;4(9):1179-84. [PubMed: 16096373]

9. Zeng Y. Principles of micro-RNA production and maturation. Oncogene 2006;25(46):6156-62. [PubMed: 17028594]

10. Kim VN. Small RNAs: classification, biogenesis, and function. Mol Cells 2005;19(1):1-15. [PubMed: 15750334] 
11. Tang G. siRNA and miRNA: an insight into RISCs. Trends Biochem Sci 2005;30(2):106-14. [PubMed: 15691656]

12. Cullen BR. Transcription and processing of human microRNA precursors. Mol Cell 2004;16(6):8615. [PubMed: 15610730]

13. Filipowicz W, Jaskiewicz L, Kolb FA, Pillai RS. Post-transcriptional gene silencing by siRNAs and miRNAs. Curr Opin Struct Biol 2005;15(3):331-41. [PubMed: 15925505]

14. Gregory RI, Yan KP, Amuthan G, Chendrimada T, Doratotaj B, Cooch N, Shiekhattar R. The Microprocessor complex mediates the genesis of microRNAs. Nature 2004;432(7014):235-40. [PubMed: 15531877]

15. Rodriguez A, Griffiths-Jones S, Ashurst JL, Bradley A. Identification of mammalian microRNA host genes and transcription units. Genome Res 2004;14(10A):1902-10. [PubMed: 15364901]

16. Baskerville S, Bartel DP. Microarray profiling of microRNAs reveals frequent coexpression with neighboring miRNAs and host genes. Rna 2005;11(3):241-7. [PubMed: 15701730]

17. Lin SL, Miller JD, Ying SY. Intronic MicroRNA (miRNA). J Biomed Biotechnol 2006;2006(4): 26818. [PubMed: 17057362]

18. Ying SY, Lin SL. Current perspectives in intronic micro RNAs (miRNAs). J Biomed Sci 2006;13 (1):5-15. [PubMed: 16228283]

19. Hammond SM. Dicing and slicing: the core machinery of the RNA interference pathway. FEBS Lett 2005;579(26):5822-9. [PubMed: 16214139]

20. Bohmert K, Camus I, Bellini C, Bouchez D, Caboche M, Benning C. AGO1 defines a novel locus of Arabidopsis controlling leaf development. Embo J 1998;17(1):170-80. [PubMed: 9427751]

21. Jabri E. P-bodies take a RISC. Nat Struct Mol Biol 2005;12(7):564. [PubMed: 15999108]

22. Liu J, Valencia-Sanchez MA, Hannon GJ, Parker R. MicroRNA-dependent localization of targeted mRNAs to mammalian P-bodies. Nat Cell Biol 2005;7(7):719-23. [PubMed: 15937477]

23. Pillai RS, Bhattacharyya SN, Artus CG, Zoller T, Cougot N, Basyuk E, Bertrand E, Filipowicz W. Inhibition of translational initiation by Let-7 MicroRNA in human cells. Science 2005;309(5740): 1573-6. [PubMed: 16081698]

24. Liu J, Carmell MA, Rivas FV, Marsden CG, Thomson JM, Song JJ, Hammond SM, Joshua-Tor L, Hannon GJ. Argonaute2 is the catalytic engine of mammalian RNAi. Science 2004;305(5689):143741. [PubMed: 15284456]

25. Chan SP, Slack FJ. microRNA-Mediated Silencing Inside P-Bodies. RNA Biol 2006;3(3):97-100. [PubMed: 17179742]

26. Jackson RJ, Standart N. How do microRNAs regulate gene expression? Sci STKE 2007;2007 (367):re1. [PubMed: 17200520]

27. John B, Enright AJ, Aravin A, Tuschl T, Sander C, Marks DS. Human MicroRNA targets. PLoS Biol 2004;2(11):e363. [PubMed: 15502875]

28. Krek A, Grun D, Poy MN, Wolf R, Rosenberg L, Epstein EJ, MacMenamin P, da Piedade I, Gunsalus KC, Stoffel M, Rajewsky N. Combinatorial microRNA target predictions. Nat Genet 2005;37(5): 495-500. [PubMed: 15806104]

29. Lewis BP, Burge CB, Bartel DP. Conserved seed pairing, often flanked by adenosines, indicates that thousands of human genes are microRNA targets. Cell 2005;120(1):15-20. [PubMed: 15652477]

30. Enright AJ, John B, Gaul U, Tuschl T, Sander C, Marks DS. MicroRNA targets in Drosophila. Genome Biol 2003;5(1):R1. [PubMed: 14709173]

31. Kiriakidou M, Nelson PT, Kouranov A, Fitziev P, Bouyioukos C, Mourelatos Z, Hatzigeorgiou A. A combined computational-experimental approach predicts human microRNA targets. Genes Dev 2004;18(10):1165-78. [PubMed: 15131085]

32. Rajewsky N, Socci ND. Computational identification of microRNA targets. Dev Biol 2004;267(2): 529-35. [PubMed: 15013811]

33. Rehmsmeier M, Steffen P, Hochsmann M, Giegerich R. Fast and effective prediction of microRNA/ target duplexes. Rna 2004;10(10):1507-17. [PubMed: 15383676]

34. Stark A, Brennecke J, Russell RB, Cohen SM. Identification of Drosophila MicroRNA targets. PLoS Biol 2003;1(3):E60. [PubMed: 14691535] 
35. Miranda KC, Huynh T, Tay Y, Ang YS, Tam WL, Thomson AM, Lim B, Rigoutsos I. A patternbased method for the identification of MicroRNA binding sites and their corresponding heteroduplexes. Cell 2006;126(6):1203-17. [PubMed: 16990141]

36. Hackl H, Burkard TR, Sturn A, Rubio R, Schleiffer A, Tian S, Quackenbush J, Eisenhaber F, Trajanoski Z. Molecular processes during fat cell development revealed by gene expression profiling and functional annotation. Genome Biol 2005;6(13):R108. [PubMed: 16420668]

37. Ambros V. microRNAs: tiny regulators with great potential. Cell 2001;107(7):823-6. [PubMed: 11779458]

38. Lai EC. Micro RNAs are complementary to $3^{\prime}$ UTR sequence motifs that mediate negative posttranscriptional regulation. Nat Genet 2002;30(4):363-4. [PubMed: 11896390]

39. Hurst LD. Preliminary assessment of the impact of microRNA-mediated regulation on coding sequence evolution in mammals. J Mol Evol 2006;63(2):174-82. [PubMed: 16786435]

40. Lewis BP I, Shih H, Jones-Rhoades MW, Bartel DP, Burge CB. Prediction of mammalian microRNA targets. Cell 2003;115(7):787-98. [PubMed: 14697198]

41. Abderrahmani A, Plaisance V, Lovis P, Regazzi R. Mechanisms controlling the expression of the components of the exocytotic apparatus under physiological and pathological conditions. Biochem Soc Trans 2006;34(Pt 5):696-700. [PubMed: 17052177]

42. Cuellar TL, McManus MT. MicroRNAs and endocrine biology. J Endocrinol 2005;187(3):327-32. [PubMed: 16423811]

43. Krutzfeldt J, Stoffel M. MicroRNAs: a new class of regulatory genes affecting metabolism. Cell Metab 2006;4(1):9-12. [PubMed: 16814728]

44. Mello CC, Czech MP. Micromanaging insulin secretion. Nat Med 2004;10(12):1297-8. [PubMed: 15580250]

45. Lee RC, Feinbaum RL, Ambros V. The C. elegans heterochronic gene lin-4 encodes small RNAs with antisense complementarity to lin-14. Cell 1993;75(5):843-54. [PubMed: 8252621]

46. Slack FJ, Basson M, Liu Z, Ambros V, Horvitz HR, Ruvkun G. The lin-41 RBCC gene acts in the C. elegans heterochronic pathway between the let-7 regulatory RNA and the LIN-29 transcription factor. Mol Cell 2000;5(4):659-69. [PubMed: 10882102]

47. Kajimoto K, Naraba H, Iwai N. MicroRNA and 3T3-L1 pre-adipocyte differentiation. Rna 2006;12 (9):1626-32. [PubMed: 16870994]

48. Esau C, Kang X, Peralta E, Hanson E, Marcusson EG, Ravichandran LV, Sun Y, Koo S, Perera RJ, Jain R, Dean NM, Freier SM, Bennett CF, Lollo B, Griffey R. MicroRNA-143 regulates adipocyte differentiation. J Biol Chem 2004;279(50):52361-5. [PubMed: 15504739]

49. Teleman AA, Maitra S, Cohen SM. Drosophila lacking microRNA miR-278 are defective in energy homeostasis. Genes Dev 2006;20(4):417-22. [PubMed: 16481470]

50. Xu P, Vernooy SY, Guo M, Hay BA. The Drosophila microRNA Mir-14 suppresses cell death and is required for normal fat metabolism. Curr Biol 2003;13(9):790-5. [PubMed: 12725740]

51. Ambros V. MicroRNA pathways in flies and worms: growth, death, fat, stress, and timing. Cell 2003;113(6):673-6. [PubMed: 12809598]

52. Boehm M, Slack FJ. MicroRNA control of lifespan and metabolism. Cell Cycle 2006;5(8):837-40. [PubMed: 16627994]

53. Poy MN, Eliasson L, Krutzfeldt J, Kuwajima S, Ma X, Macdonald PE, Pfeffer S, Tuschl T, Rajewsky N, Rorsman P, Stoffel M. A pancreatic islet-specific microRNA regulates insulin secretion. Nature 2004;432(7014):226-30. [PubMed: 15538371]

54. Plaisance V, Abderrahmani A, Perret-Menoud V, Jacquemin P, Lemaigre F, Regazzi R. MicroRNA-9 controls the expression of Granuphilin/Slp4 and the secretory response of insulin-producing cells. J Biol Chem 2006;281(37):26932-42. [PubMed: 16831872]

55. Babak T, Zhang W, Morris Q, Blencowe BJ, Hughes TR. Probing microRNAs with microarrays: tissue specificity and functional inference. Rna 2004;10(11):1813-9. [PubMed: 15496526]

56. Nelson PT, Baldwin DA, Kloosterman WP, Kauppinen S, Plasterk RH, Mourelatos Z. RAKE and LNA-ISH reveal microRNA expression and localization in archival human brain. Rna 2006;12(2): 187-91. [PubMed: 16373485] 
57. Mersey BD, Jin P, Danner DJ. Human microRNA (miR29b) expression controls the amount of branched chain alpha-ketoacid dehydrogenase complex in a cell. Hum Mol Genet 2005;14(22):33717. [PubMed: 16203741]

58. Fjose A, Drivenes O. RNAi and microRNAs: from animal models to disease therapy. Birth Defects Res C Embryo Today 2006;78(2):150-71. [PubMed: 16847892]

59. Ricke DO, Wang S, Cai R, Cohen D. Genomic approaches to drug discovery. Curr Opin Chem Biol 2006;10(4):303-8. [PubMed: 16822705]

60. Silva JM, Hammond SM, Hannon GJ. RNA interference: a promising approach to antiviral therapy? Trends Mol Med 2002;8(11):505-8. [PubMed: 12421679]

61. Slack FJ, Weidhaas JB. MicroRNAs as a potential magic bullet in cancer. Future Oncol 2006;2(1): 73-82. [PubMed: 16556074]

62. Davis S, Lollo B, Freier S, Esau C. Improved targeting of miRNA with antisense oligonucleotides. Nucleic Acids Res 2006;34(8):2294-304. [PubMed: 16690972]

63. Esau C, Davis S, Murray SF, Yu XX, Pandey SK, Pear M, Watts L, Booten SL, Graham M, McKay R, Subramaniam A, Propp S, Lollo BA, Freier S, Bennett CF, Bhanot S, Monia BP. miR-122 regulation of lipid metabolism revealed by in vivo antisense targeting. Cell Metab 2006;3(2):87-98. [PubMed: 16459310]

64. Mourelatos Z, Dostie J, Paushkin S, Sharma A, Charroux B, Abel L, Rappsilber J, Mann M, Dreyfuss G. miRNPs: a novel class of ribonucleoproteins containing numerous microRNAs. Genes Dev 2002;16(6):720-8. [PubMed: 11914277]

65. Miska EA, Alvarez-Saavedra E, Townsend M, Yoshii A, Sestan N, Rakic P, Constantine-Paton M, Horvitz HR. Microarray analysis of microRNA expression in the developing mammalian brain. Genome Biol 2004;5(9):R68. [PubMed: 15345052]

66. Roldo C, Missiaglia E, Hagan JP, Falconi M, Capelli P, Bersani S, Calin GA, Volinia S, Liu CG, Scarpa A, Croce CM. MicroRNA expression abnormalities in pancreatic endocrine and acinar tumors are associated with distinctive pathologic features and clinical behavior. J Clin Oncol 2006;24(29): 4677-84. [PubMed: 16966691]

67. Kulshreshtha R, Ferracin M, Wojcik SE, Garzon R, Alder H, Agosto-Perez FJ, Davuluri R, Liu CG, Croce CM, Negrini M, Calin GA, Ivan M. A MicroRNA Signature of Hypoxia. Mol Cell Biol. 2006

68. Marsit CJ, Eddy K, Kelsey KT. MicroRNA responses to cellular stress. Cancer Res 2006;66(22): 10843-8. [PubMed: 17108120]

69. van Rooij E, Sutherland LB, Liu N, Williams AH, McAnally J, Gerard RD, Richardson JA, Olson EN. A signature pattern of stress-responsive microRNAs that can evoke cardiac hypertrophy and heart failure. Proc Natl Acad Sci U S A 2006;103(48):18255-60. [PubMed: 17108080]

70. Calin GA, Croce CM. Genomics of chronic lymphocytic leukemia microRNAs as new players with clinical significance. Semin Oncol 2006;33(2):167-73. [PubMed: 16616063]

71. Tahiliani AG, Beinlich CJ. Pantothenic acid in health and disease. Vitam Horm 1991;46:165-228. [PubMed: 1746161]

72. Jackowski S, Rock CO. Regulation of coenzyme A biosynthesis. J Bacteriol 1981;148(3):926-32. [PubMed: 6796563]

73. Robishaw JD, Neely JR. Coenzyme A metabolism. Am J Physiol 1985;248(1 Pt 1):E1-9. [PubMed: 2981478]

74. Rock CO, Calder RB, Karim MA, Jackowski S. Pantothenate kinase regulation of the intracellular concentration of coenzyme A. J Biol Chem 2000;275(2):1377-83. [PubMed: 10625688]

75. Vallari DS, Jackowski S, Rock CO. Regulation of pantothenate kinase by coenzyme A and its thioesters. J Biol Chem 1987;262(6):2468-71. [PubMed: 3029083]

76. Leonardi R, Zhang YM, Rock CO, Jackowski S. Coenzyme A: back in action. Prog Lipid Res 2005;44 (2-3):125-53. [PubMed: 15893380]

77. Gordon N. Pantothenate kinase-associated neurodegeneration (Hallervorden-Spatz syndrome). Eur J Paediatr Neurol 2002;6(5):243-7. [PubMed: 12374576]

78. Hayflick SJ. Unraveling the Hallervorden-Spatz syndrome: pantothenate kinase-associated neurodegeneration is the name. Curr Opin Pediatr 2003;15(6):572-7. [PubMed: 14631201] 
79. Zhou B, Westaway SK, Levinson B, Johnson MA, Gitschier J, Hayflick SJ. A novel pantothenate kinase gene (PANK2) is defective in Hallervorden-Spatz syndrome. Nat Genet 2001;28(4):345-9. [PubMed: 11479594]

80. Ni X, Ma Y, Cheng H, Jiang M, Ying K, Xie Y, Mao Y. Cloning and characterization of a novel human pantothenate kinase gene. Int J Biochem Cell Biol 2002;34(2):109-15. [PubMed: 11809413]

81. Ramaswamy G, Karim MA, Murti KG, Jackowski S. PPARalpha controls the intracellular coenzyme A concentration via regulation of PANK1alpha gene expression. J Lipid Res 2004;45(1):17-31. [PubMed: 14523052]

82. Green S. PPAR: a mediator of peroxisome proliferator action. Mutat Res 1995;333(1-2):101-9. [PubMed: 8538617]

83. Icre G, Wahli W, Michalik L. Functions of the peroxisome proliferator-activated receptor (PPAR) alpha and beta in skin homeostasis, epithelial repair, and morphogenesis. J Investig Dermatol Symp Proc 2006;11(1):30-5.

84. Johnson EF, Palmer CN, Griffin KJ, Hsu MH. Role of the peroxisome proliferator-activated receptor in cytochrome P450 4A gene regulation. Faseb J 1996;10(11):1241-8. [PubMed: 8836037]

85. Lefebvre P, Chinetti G, Fruchart JC, Staels B. Sorting out the roles of PPAR alpha in energy metabolism and vascular homeostasis. J Clin Invest 2006;116(3):571-80. [PubMed: 16511589]

86. Skrede S, Sorensen HN, Larsen LN, Steineger HH, Hovik K, Spydevold OS, Horn R, Bremer J. Thia fatty acids, metabolism and metabolic effects. Biochim Biophys Acta 1997;1344(2):115-31. [PubMed: 9030189] 




\section{Argonaute-bound miRNA mediates 'target mRNA' recognition miRNA-bound Argonaute protein mediates inhibition of polypeptide formation}

Figure 1.

MiRNAs function by recognizing a "target mRNA" and impairing the formation of a polypeptide from that mRNA. MiRNAs (purple) guide the Argonaute proteins (red) to a “target” mRNA (green). After miRNAs hybridize to a sequence on the 3'UTR (untranslated region) of the mRNA, the Argonaute protein helps to mediate translational inhibition and/or mRNA sequestration and degradation. 


\section{A miR-103 agcagcauuguacagggcuauga miR-107 agcagcauuguacagggcuauca}

B

hsa-miR-107

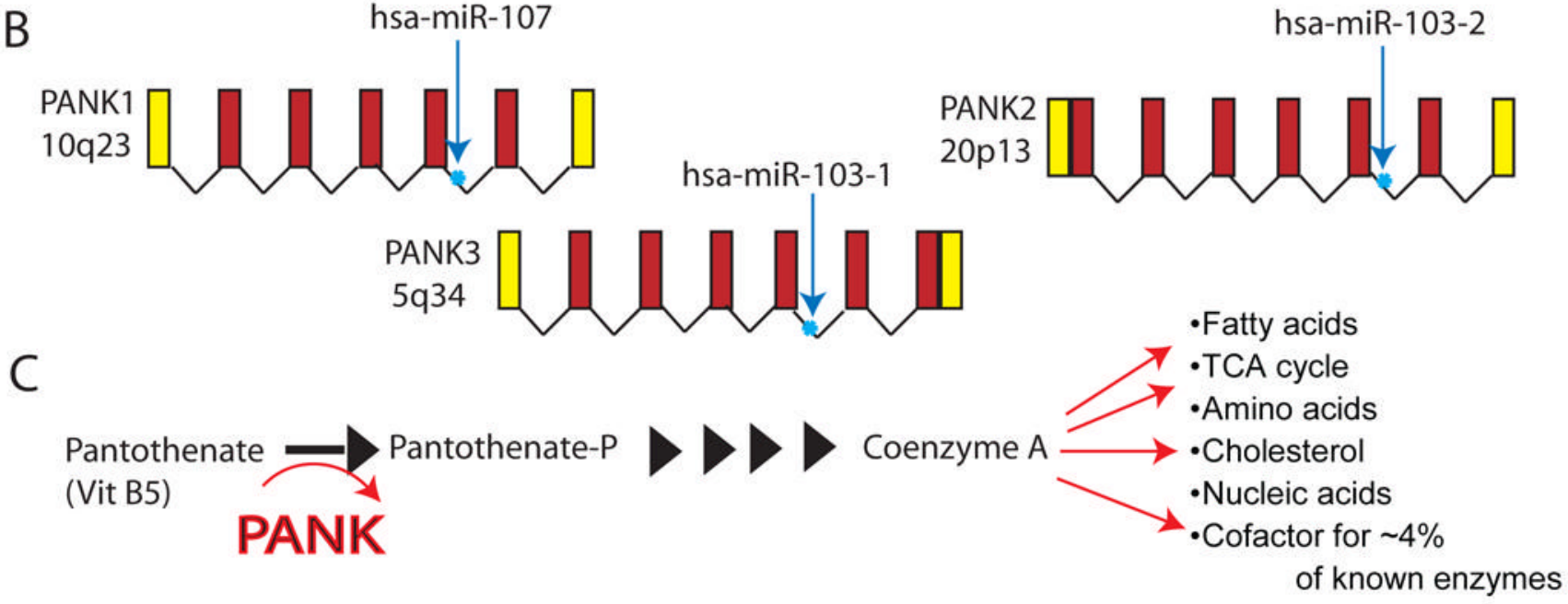

Figure 2.

A. MiR-103 and miR-107 are paralogs, which differ only at a single nucleotide near the $3^{\prime}$ end of the miRNAs. B. For all known vertebrate species, each miR-103/107 paralog exists within an intron in a gene which also encodes the pantothenate kinase enzyme, PANK. PANK genes are shown with exons as rectangles and introns as crooked lines. Note: the exon/intron lengths on these gene diagrams are not to scale. C. The pathway in which PANK participates is universal, involving the phosphorylation of pantothenate as a rate-determining step in the formation of Coenzyme A (CoA). In turn, CoA participates in many metabolic and other biochemical reactions in all known biological species. 


\begin{tabular}{|c|c|c|c|c|c|c|c|c|c|c|c|c|c|}
\hline & \begin{tabular}{|l|}
$\mathrm{miR}-$ \\
$103 / 7$
\end{tabular} \mid & \begin{tabular}{|l} 
miR- \\
29
\end{tabular} & \begin{tabular}{|l|}
$\mathrm{miR}-$ \\
23
\end{tabular} & \begin{tabular}{|l|}
$\mathrm{miR}-$ \\
24
\end{tabular} & \begin{tabular}{|l|}
$\mathrm{miR}-$ \\
$125 \mathrm{~b}$
\end{tabular} & $\begin{array}{l}\mathrm{miR}- \\
124 a\end{array}$ & & \begin{tabular}{|l}
$\mathrm{miR}-$ \\
$103 / 7$
\end{tabular} & $\begin{array}{l}\text { miR- } \\
29\end{array}$ & \begin{tabular}{|l|}
$\mathrm{miR}-$ \\
23
\end{tabular} & \begin{tabular}{|l|}
$\mathrm{miR}-$ \\
24
\end{tabular} & $\begin{array}{l}\mathrm{miR}- \\
125 \mathrm{~b}\end{array}$ & $\begin{array}{l}\mathrm{miR}- \\
124 a\end{array}$ \\
\hline TOTAL \# targets & & & & & & & Glucose & & & & & & \\
\hline PREDICTED: & & & & & & & PFKFB4 & & & & & & \\
\hline MIRANDA 2006(1) & 1131 & 1375 & 1227 & 3100 & 1190 & 1173 & PFKFB2 & & & & & & \\
\hline MIRANDA 2005(2) & 798 & 595 & 195 & 2176 & 1088 & 727 & FBP1 & 1 & 1 & & & & \\
\hline PICTAR (3) & 737 & 576 & 472 & 368 & 531 & 787 & PFKFB3 & & & & & & \\
\hline TARGETSCAN (4) & 332 & 326 & 533 & 303 & 423 & 654 & Glycolysis & & & & & & \\
\hline SUM & 2998 & 2872 & 2427 & 5947 & 3232 & 3341 & PFKP & & & & & & 1 \\
\hline Lipids & & & & & & & PFKL & & & & 1 & & \\
\hline FASN & 12 & & & & & & PFKM & & & & & & \\
\hline ACSL4 & & & & & & & HK1 & & & & & & \\
\hline BG1 & & & & & & & HK2 & & & & 2 & & \\
\hline ACSL1 & & & & & & & Glycogen & & & & & & \\
\hline $\mathrm{OGDH}$ & & & & & & & GSK3B & & & & & & \\
\hline ACADVL & & & & & & & NIN & & & & & & \\
\hline ACADS & & & & 12 & & & PYGB & & & & & & \\
\hline HADHSC & & & & & & & GYS1 & & & & & & \\
\hline EHHADH & & & & & & & GSK3A & & & & 12 & & \\
\hline$A C L Y$ & 12 & & & & & & $\mathrm{H} 6 \mathrm{PD}$ & & & & & & \\
\hline CPT1B & & & & & & & TCA Cycle & & & & & & \\
\hline ACOX1 & 12 & & & & & & CS & & & & & & \\
\hline ACAS2 & & & & & & & IDH3B & & & & & & 1 \\
\hline $\mathrm{ACACB}$ & & & & & & & IDH3A & & & & & & \\
\hline ACACA & & & & & & & IDH2 & & & & 1 & & \\
\hline EGLF8 & 3 & & & & & & IDH1 & & & 1 & & & \\
\hline$S C D$ & & & & & & & Other & & & & & & \\
\hline Pyruvate & & & & & & & PTGS2 & & & & & & \\
\hline PISD & & & & & & & PTGS1 & & & & & & \\
\hline $\mathrm{PDHB}$ & & & & & & & LRP1 & 2 & & & & & \\
\hline PDK4 & 1234 & & & & & & LRP6 & & & & & & \\
\hline PDK2 & & & & & & 12 & LRP1B & 2 & & & & & \\
\hline PDK1 & & & & & & & PHGDH & & & & & & \\
\hline PDPK1 & & & & & & & HMGCR & & 12 & & & 2 & \\
\hline PDP2 & & & & 2 & & & SPTCL1 & 23 & & & & & 1 \\
\hline LDHB & & & 12 & & & & Glutamate & & & & & & \\
\hline LDHA & & & & & & & GLUD1 & 23 & & & & & \\
\hline PDPR & & & & & & & GLUD2 & 13 & & & & & \\
\hline PPAR & & & & & & & GLS & & & & & & \\
\hline PPARA & & & & 2 & 2 & & GLS2 & 1 & & & & & \\
\hline \multicolumn{14}{|l|}{ PPARB } \\
\hline \multicolumn{14}{|l|}{ PPARG } \\
\hline \multicolumn{14}{|l|}{ PPARBP } \\
\hline PPARGC1A & 2 & 2 & 123 & 2 & & & & & & & & & \\
\hline PPARGC1B & & & & & & & & & & & & & \\
\hline
\end{tabular}

Figure 3.

MiR-103/107 show an unusual tendency to target mRNAs in the lipid and pyruvate metabolic pathways. This chart relates six different human brain-enriched miRNAs (columns) to metabolism-related "target mRNAs" (rows) with predictions from different databases as to which miRNAs are predicted to target which mRNAs (shaded rectangles). The top left portion of the chart shows the four different databases that were used (see references in text). The numbers 1-4 are also used in the chart to indicate which database(s) predicted each highlighted miRNA/mRNA pair:

(1) MiRANDA, 2005 build via MSKCC: http://cbio.mskcc.org/cgi-bin/mirnaviewer/ mirnaviewer.pl 
(2) MiRANDA, 2006 build via Sanger: http://microrna.sanger.ac.uk/cgi-bin/targets/v4/ hit_list.pl?

(3) PicTar: http://pictar.bio.nyu.edu/

(4) TargetScan 2006 build: http://www.targetscan.org/mamm_30/ 


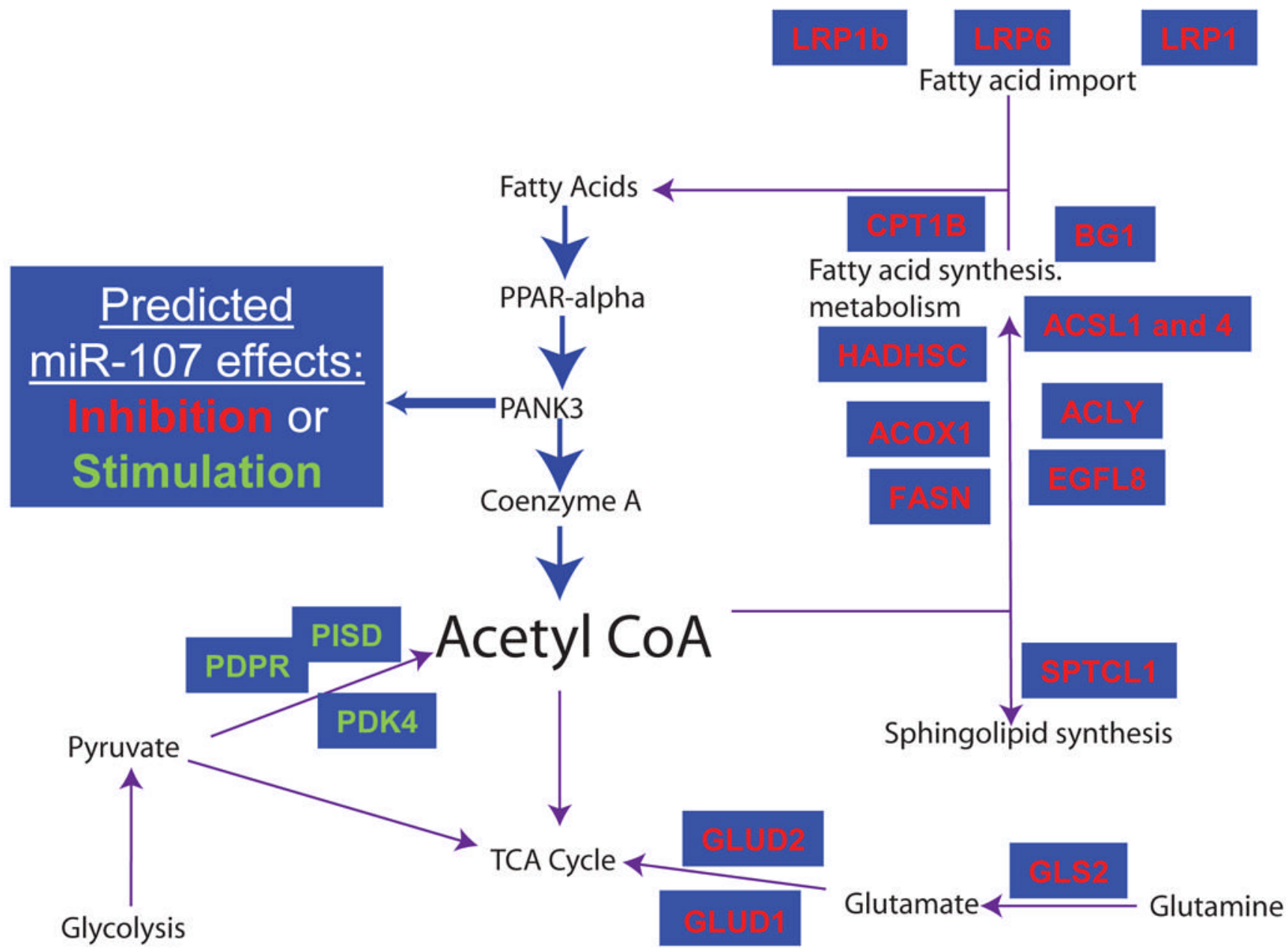

\section{Predicted net effects:}

PANK: Increased Acetyl CoA

miR-103/7: Increased Acetyl CoA and Decreased Lipid synthesis/metabolism

Figure 4.

MiR-103/107 and PANKs may constitute coordinated transcription units with synergistic cellular effects concerning cellular acetyl-CoA levels and other metabolic pathway elements. A. A diagram shows a metabolic pathway that has been previously determined, along with some of the metabolic nodes which are predicted to be inhibited (red) or stimulated (green; through decrease of inhibitory targets) by miR-103/7. MiR-107 may be stimulated coordinately with PANK1. B. Like PANKs, miR-103/7 may function to increase cellular acetyl-CoA levels, and miR-103/7 may also inhibit the synthesis and metabolism of cellular lipids. 


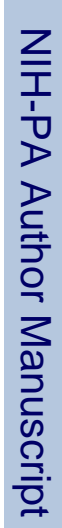

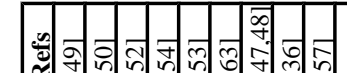

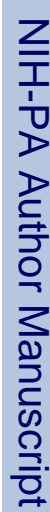

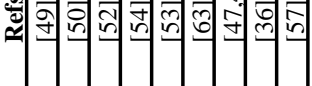

.
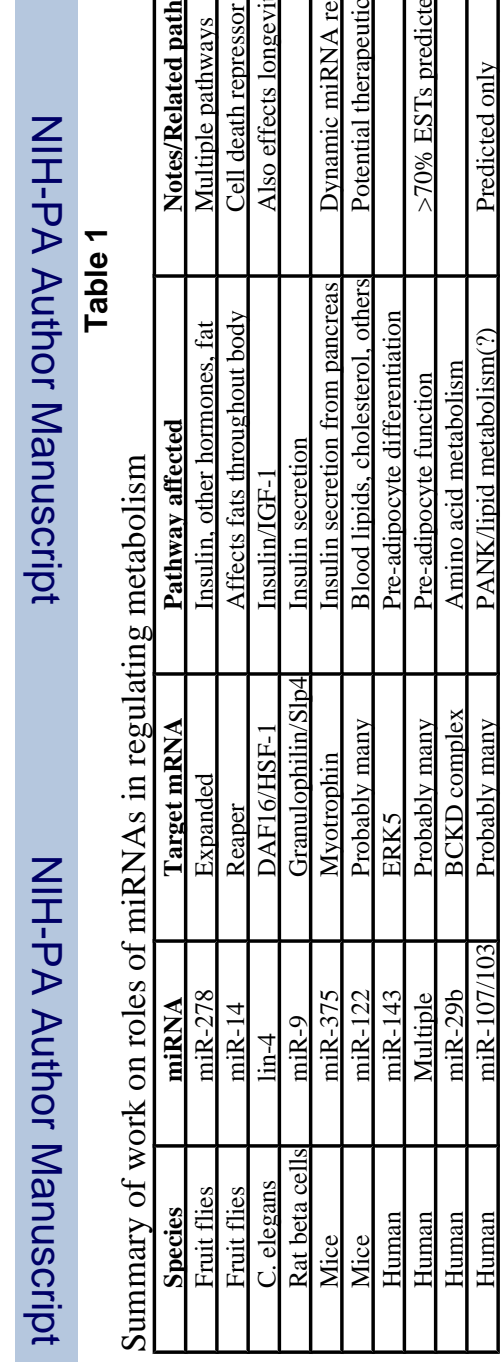

Mol Genet Metab. Author manuscript; available in PMC 2008 July 1. 